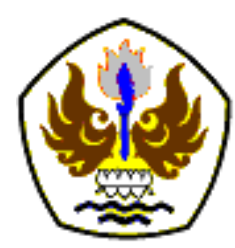

INFOMATEK

Volume 19 Nomor 2 Desember 2017

\title{
PEMILIHAN ALTERNATIF JARINGAN DISTRIBUSI UTAMA (JDU) UNTUK PENGEMBANGAN SPAM REGIONAL DI KABUPATEN SUMEDANG, KABUPATEN MAJALENGKA, KABUPATEN CIREBON DAN KOTA CIREBON
}

\author{
Evi Afiatun"), Sri Wahyuni, Ilvan Prasetia Nugraha \\ Program Studi Teknik Lingkungan \\ Fakultas Teknik- Universitas Pasundan
}

\begin{abstract}
Abstrak: Air merupakan kebutuhan pokok bagi kehidupan dan perlu adanya strategi dalam pemenuhannya. Perencanaan ini menggunakan strategi pemenuhan kebutuhan air dengan skema Sistem Penyediaan Air Minum (SPAM) Regional. Sumber air yang digunakan adalah Waduk Jatigede dengan alokasi untuk air minum sebesar 3.500 liter/detik dan berlokasi di Kecamatan Jatigede, Kabupaten Sumedang. Ruang lingkup wilayah dalam kajian ini meliputi 11 (sebelas) Kecamatan dalam 4 (Empat) Kabupaten/ Kota yaitu Kabupaten Sumedang, Kabupaten Majalengka, Kabupaten Cirebon dan Kota Cirebon yang dalam Rencana Tata Ruang Wilayah (RTRW) memiliki arahan sebagai kawasan perkotaan. Kebutuhan air minum rata-rata di wilayah kajian adalah 1.333,33 liter/detik, kebutuhan air hari maksimum (Qmaks day) adalah 1.466,66 liter/detik, dan kebutuhan jam puncak ( $Q$ peak hour) adalah 2.000 liter/detik. Perencanaan sistem Jaringan Distribusi Utama (JDU) disimulasikan dengan menggunakan aplikasi EPANET 2.0. Perencanaan Reservoir dan offtake memperhitungkan cakupan pelayanan yang akan dilayani. Perencanaan jaringan distribusi menggunakan 2 (dua) alternatif. Alternatif pertama menggunakan dua jenis pipa berbeda serta tidak menggunakan Bak Pelepas Tekan (BPT). Sedangkan, alternatif kedua menggunakan satu jenis pipa dan menggunakan Bak Pelepas Tekan (BPT). Berdasarkan analisis perbandingan kedua alternatif tersebut, terpilih alternatif kedua dengan mempertimbangkan segi ekonomis dan hidrolis lebih efektif.
\end{abstract}

Kata kunci: Air Minum, Jaringan Distribusi, EPANET 2.0, Pemilihan Alternatif

\section{PENDAHULUAN}

Air merupakan kebutuhan pokok bagi mahluk hidup termasuk manusia. Keberadaan air baik kualitas maupun kuantitas akan berpengaruh pada kehidupan manusia. Sumber air yang direncanakan pada perencanaan sistem air minum ini bersumber dari Waduk Jatigede yang berlokasi di Kecamatan Jatigede, Kabupaten Sumedang. Sumber air Waduk

*evi_afiatun@unpas.ac.id
Jatigede menyediakan air bersih bagi Kabupaten Majalengka, Kabupaten Cirebon, Kota Cirebon dan kawasan sekitarnya dengan kapasitas 3.500 liter/detik.

Kebutuhan air baku untuk berbagai keperluan terutama air bersih untuk rumah tangga, tempat-tempat umum, industri dan lain-lain akan terus meningkat dari waktu ke waktu sejalan dengan lajunya pembangunan di berbagai sektor dan bidang serta jumlah 
penduduk yang terus bertambah. Di sisi lain jumlah penyediaan dan prasarana air baku yang ada saat ini relatif terbatas sehingga belum dapat memenuhi semua kebutuhan tersebut.

Tujuan dalam studi ini adalah pemilihan alternatif Jaringan Distribusi Utama (JDU) untuk pengembangan pelayanan SPAM Regional di Kabupaten Sumedang, Kabupaten Majalengka, Kabupaten Cirebon dan Kota Cirebon serta merencanakan kapasitas reservoir distribusi yang dibutuhkan ditinjau dari aspek teknis.

Oleh karena itu, diharapkan dengan adanya penelitian ini dapat mengetahui tingkat penyediaan (supply) dan kebutuhan (demand) air minum di Kota Cirebon sesuai dengan rencana pengembangan wilayah, dapat merumuskan teknis untuk Perencanaan Reservoir dan Pipa Jaringan Distribusi Utama (JDU) serta menentukan lokasi offtake/ Reservoir di Kabupaten Sumedang, Kabupaten Majalengka, Kabupaten Cirebon dan Kota Cirebon.

Tabel 1

Wilayah Kajian (Bappeda Jabar [1])

\begin{tabular}{|c|l|l|}
\hline No & \multicolumn{1}{|c|}{ Kabupaten/ Kota } & Kecamatan \\
\hline 1 & Kabupaten Sumedang & Tomo \\
\hline 2 & Kabupaten Majalengka & Kadipaten \\
\cline { 3 - 3 } & & Jatiwangi \\
\cline { 3 - 3 } & & Pelasah \\
\cline { 3 - 3 } & & Sumberjaya \\
\cline { 3 - 3 } & & Kertajati \\
\hline 3 & \multirow{2}{*}{ Kabupaten Cirebon } & Palimanan \\
\cline { 3 - 3 } & & Plumbon \\
\cline { 3 - 3 } & & Weru \\
\cline { 3 - 3 } & & Klangenan \\
\hline 4 & Kota Cirebon & Harjamukti \\
\hline
\end{tabular}

Ruang lingkup wilayah dalam kajian ini seperti tertera pada Tabel 1, meliputi 4 (empat) Kabupaten/ Kota yaitu berada di Kabupaten Sumedang, Kabupaten Majalengka, Kabupaten Cirebon dan Kota Cirebon.

\section{KRITERIA PERENCANAAN}

\subsection{Reservoir}

Kapasitas reservoir ini juga harus mampu mengatasi kebutuhan air di saat puncak. Besarnya suplai ke reservoir merupakan debit rata-rata yaitu sebesar $4,17 \%$, maka perhitungan kapasitas reservoir dapat langsung dihitung dengan memperkirakannya sebesar 15\%-30\% (Steel [2]) atau 15\%-20\% (Hammer [3]) dari debit rata-rata. Kapasitas reservoir dihitung sebesar (15\%-30\%).

\subsection{Jaringan Distribusi}

Kriteria desain yang biasa dipakai untuk pipa induk adalah:

a) Diameter pipa minimum adalah $150 \mathrm{~mm}$.

b) Kecepatan aliran minimum di dalam pipa adalah 0,3 $\mathrm{m} /$ detik sedangkan kecepatan aliran maksimum berkisar $3 \mathrm{~m} /$ detik.

c) Tekanan pada sistem harus dapat menjangkau titik kritis dengan sisa tekanan tidak kurang dari $10 \mathrm{~m}$.

d) Tekanan statis yang tersedia tidak lebih dari $70 \mathrm{~m}$.

e) Pipa tidak melayani penyadapan langsung ke konsumen.

f) Pipa ini dapat mengalirkan air sampai akhir tahap perencanaan dengan debit puncak.

Dalam menentukan kekasaran pipa menggunakan kekasaran pipa HazenWilliams. Untuk menentukan jenis pipa yang 
akan diaplikasikan dalam penerapan harus melihat dari kekasaran pipa tersebut. Nilai nilai kekasaran pipa dapat dilihat pada Tabel 2.

\section{Tabel 2}

Koefisien Kekasaran Pipa Hazen-Williams

(Evet dkk. [4])

\begin{tabular}{|l|c|}
\hline \multicolumn{1}{|c|}{ Pipe Type } & K \\
\hline $\begin{array}{l}\text { Extremely smooth and straight } \\
\text { pipes }\end{array}$ & 140 \\
\hline New steel or cast iron & 130 \\
\hline Wood ; concrete & 120 \\
\hline New riveted steel; vitrifield & 110 \\
\hline Old cast iron & 100 \\
\hline Very old and corroded cast iron & 80 \\
\hline
\end{tabular}

\section{DASAR PERENCANAAN}

Dalam perencanaan ini diperlukan metode untuk melakukan kajian mengenai pemilihan alternatif Jaringan Distribusi Utama (JDU) regional dengan memanfaatkan skema SPAM Regional, di mana metodologi yang dilakukan terdiri atas metode pendekatan studi, metode pengumpulan data, dan metode analisis perencanaan.

Perencanaan yang dilakukan terhadap data yang didapat dengan melakukan tindakan sebagai berikut:

a) Analisis data profil daerah dari RTRW/ RDTR menentukan daerah yang akan dilayani dengan kategori wajib layanan air minum (yang memiliki ciri perkotaan).

b) Data Business Plan dan profil PDAM daerah untuk melihat tingkat layanan dan rencana pelayanan PDAM di masa yang akan datang.

c) Analisis data kependudukan dengan melakukan proyeksi penduduk guna mendapatkan data kebutuhan air minum dalam kurun waktu yang ditetapkan.

d) Perencanaan terhadap data eksisting diolah dengan menggunakan aplikasi EPANET 2.0 yang kemudian dituangkan dalam bentuk perencanaan Jaringan Distribusi Utama (JDU) termasuk aksesoris dan perlengkapan jalur air lainnya. Untuk analisis menggunakan EPANET 2.0 terdapat beberapa langkah dalam pengerjaannya, untuk lebih jelasnya sebagai berikut :

1. Pengolahan input data model. Model EPANET 2.0 yang digunakan memerlukan beberapa parameter input yang harus dimasukkan untuk melakukan simulasi. Parameterparameter tersebut adalah debit, elevasi, panjang pipa, diameter pipa, koefisien kekasaran pipa dan lain-lain.

2. Penggambaran peta jaringan distribusi. Peta jaringan distribusi digambar ulang pada network map EPANET 2.0 dengan input yang sesuai dengan model eksisting dan data sekunder yang telah didapat. Input peta tahap awal meliputi ketinggian elevasi node, diameter pipa dan panjang pipa.

3. Simulasi kondisi desain. Hasil penggambaran dan input pada EPANET 2.0 disimulasikan selama 24 jam dengan memperhitungkan faktor jam puncak.

\section{HASIL DAN PEMBAHASAN}

\subsection{Analisis Kebutuhan Air Minum}

Analisis kebutuhan air merupakan pemenuhan kebutuhan dalam wilayah kajian. Pada Tabel 3 
dapat dilihat rekapitulasi kebutuhan air minum

kebutuhan non domestik pada wilayah kajian. berdasarkan kebutuhan domestik dan

Tabel 3

Rekapitulasi Kebutuhan Air Minum di Wilayah Studi

\begin{tabular}{|c|c|c|c|c|c|}
\hline No & Kabupaten & Kecamatan & Qr (L/Dtk) & $\begin{array}{l}\text { Q Maks Hari } \\
\text { (L/dtk) }\end{array}$ & $\begin{array}{c}\text { Q Peak Jam } \\
\text { (L/Dtk) }\end{array}$ \\
\hline 1. & $\begin{array}{l}\text { Kabupaten } \\
\text { Sumedang }\end{array}$ & Kecamatan Tomo & 31,52 & 34,68 & 47,29 \\
\hline 2. & \multirow{5}{*}{$\begin{array}{l}\text { Kabupaten } \\
\text { Majalengka }\end{array}$} & Kecamatan Kadipaten & 53,09 & 58,40 & 79,64 \\
\hline 3. & & Kecamatan Jatiwangi & 105,42 & 115,96 & 158,13 \\
\hline 4. & & Kecamatan Palasah & 101,58 & 111,74 & 152,38 \\
\hline 5. & & Kecamatan Sumberjaya & 102,76 & 113,04 & 154,14 \\
\hline 6. & & Kecamatan Kertajati & 184,27 & 202,69 & 276,40 \\
\hline 7. & \multirow{4}{*}{ Kabupaten Cirebon } & Kecamatan Klangenan & 99,76 & 109,73 & 149,63 \\
\hline 8. & & Kecamatan Palimanan & 120,20 & 132,22 & 180,29 \\
\hline 9. & & Kecamatan Plumbon & 142,31 & 156,54 & 213,46 \\
\hline 10. & & Kecamatan Weru & 134,40 & 147,84 & 201,59 \\
\hline 11. & Kota Cirebon & Kecamatan Harjamukti & 258,02 & 283,83 & 387,04 \\
\hline \multicolumn{3}{|c|}{ Jumlah } & 1.333 & 1.467 & 2.000 \\
\hline
\end{tabular}

Pada Tabel 3 dapat dilihat data debit kebutuhan untuk perencanaan jaringan distribusi yang terdiri dari perencanaan reservoir dan perencanaan pipa distribusi utama. Untuk perencanaan reservoir menggunakan debit rata-rata (Qr) sesuai dengan wilayah pelayanan. Dan untuk perencanaan pipa distribusi utama (JDU) menggunakan debit jam puncak ( $Q$ peak jam).

\subsection{Perhitungan Volume Reservoir/ Offtake}

Untuk menghitung kepastian reservoir ini, maka reservoir ditinjau dari fungsinya sebagai equilizing flow. Reservoir diperlukan untuk menyeimbangkan fluktuasi permukaan air harian, sehingga kebutuhan maksimum perjam dapat terpenuhi. Dalam perencanaan ini reservoir distribusi utama (Reservoir Jatigede) tidak menggunakan standar kapasitas reservoir yang berkisar 15\%-30\%, karena pada offtake terdapat reservoir yang melayani daerah pelayanannya masingmasing.

Untuk melayani 11 kecamatan pada perencanaan ini akan dibuat beberapa reservoir dan juga offtake/ reservoir cabang adalah sebagai berikut :

1. Reservoir Utama (Reservoir IPA Jatigede) yaitu melayani 11 (sebelas) kecamatan.

2. Resevoar Tomo (Kabupaten Sumedang), melayani wilayah Kecamatan Tomo.

3. Reservoir Kadipaten (Kabupaten Majalengka), melayani wilayah Kecamatan Kadipaten dan juga Kecamatan Kertajati.

4. Reservoir Jatiwangi (Kabupaten Majalengka), melayani wilayah Kecamatan Jatiwangi, Kecamatan Palasah, dan Kecamatan Sumberjaya.

5. Reservoir Palimanan (Kabupaten Cirebon), melayani wilayah Kecamatan Palimanan, 
Pemilihan Alternatif Jaringan Distribusi Utama (JDU) untuk Pengembangan SPAM Regional di Kabupaten Sumedang,

Kabupaten Majalengka, Kabupaten Cirebondan Kota Cirebon

Kecamatan Klangenan, Kecamatan 6. Reservoir Cirebon (Kota Cirebon),

Plumbon, dan Kecamatan Weru. melayani wilayah Kecamatan Harjamukti.

Tabel 4

Perhitungan Volume Reservoir

\begin{tabular}{|c|l|c|c|c|c|c|}
\hline No & Reservoir & $\begin{array}{c}\text { Persentase } \\
\text { Volume } \\
\text { Reservoir } \\
(\% / H a r i)\end{array}$ & $\begin{array}{c}\text { Debit } \\
\text { Pelayanan } \\
\left(\mathbf{m}^{3} / \text { detik }\right)\end{array}$ & $\begin{array}{c}\text { Volume } \\
\text { Reservoir } \\
\left(\mathbf{m}^{3}\right)\end{array}$ & $\begin{array}{c}\text { Jumlah } \\
\text { Reservoir }\end{array}$ & $\begin{array}{c}\text { Volume } \\
\text { per } \\
\text { Reservoir } \\
\left(\mathbf{m}^{3}\right)\end{array}$ \\
\hline 1 & $\begin{array}{l}\text { IPA Distribusi } \\
\text { Utama }\end{array}$ & - & 1,33 & 4.800 & 1 & 4.800 \\
\hline 2 & Tomo & 20 & 0,03 & 545 & 1 & 545 \\
\hline 3 & Kadipaten & 20 & 0,34 & 5.857 & 1 & 5.857 \\
\hline 4 & Jatiwangi & 20 & 0,21 & 3.597 & 1 & 3.597 \\
\hline 5 & Palimanan & 20 & 0,50 & 8.582 & 2 & 4.291 \\
\hline 6 & Cirebon & 20 & 0,26 & 4.459 & 1 & 4.459 \\
\hline
\end{tabular}

Tabel 5

Perhitungan Dimensi dan Penyediaan Lahan Reservoir

\begin{tabular}{|c|l|c|c|c|c|c|}
\hline No & \multicolumn{1}{|c|}{ Reservoir } & $\begin{array}{c}\text { Keterangan } \\
\text { Dimensi }\end{array}$ & $\begin{array}{c}\text { Kedalaman } \\
(\mathbf{m})\end{array}$ & Lebar $(\mathbf{m})$ & Panjang $(\mathbf{m})$ & $\begin{array}{c}\text { Penyediaan Lahan } \\
\left(\mathbf{m}^{2}\right)\end{array}$ \\
\hline 1 & $\begin{array}{l}\text { IPA Distribusi } \\
\text { Utama }\end{array}$ & $\mathrm{P}: \mathrm{L}=2: 1$ & 5 & 21,91 & 43,82 & 1.920 \\
\hline 2 & Tomo & $\mathrm{P}: \mathrm{L}=2: 2$ & 5 & 7,38 & 14,76 & 218 \\
\hline 3 & Kadipaten & $\mathrm{P}: \mathrm{L}=2: 3$ & 5 & 24,20 & 48,40 & 2.343 \\
\hline 4 & Jatiwangi & $\mathrm{P}: \mathrm{L}=2: 4$ & 5 & 18,97 & 37,93 & 1.439 \\
\hline 5 & Palimanan & $\mathrm{P}: \mathrm{L}=2: 5$ & 5 & 20,72 & 41,43 & 3.433 \\
\hline 6 & Cirebon & $\mathrm{P}: \mathrm{L}=2: 6$ & 5 & 21,12 & 42,23 & 1.783 \\
\hline
\end{tabular}

\subsection{Rencana Jalur}

Dalam perencanaan jaringan distribusi utama untuk pengembangan sistem penyediaan air minum di wilayah studi dengan mengikuti jaringan jalan utama yaitu jalan nasional yang melintang dari Kabupaten Sumedang hingga Kota Cirebon. Untuk lebih jelasnya dapat dilihat pada hasil analisis EPANET 2.0 yang tertera pada Gambar 1.

Gambar 1 adalah hasil dari penggambaran jalur dengan mengikuti jaringan jalan utama yaitu jalan nasional. Tabel 6 merupakan hasil analisis EPANET 2.0. 


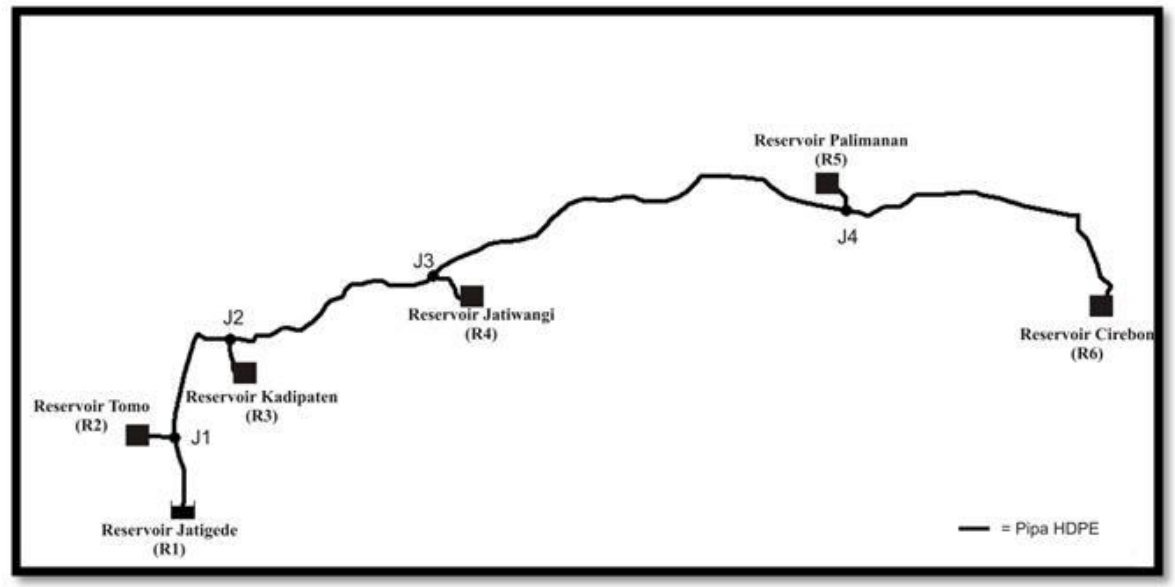

Gambar 1

Sketsa Rencana Jaringan Distribusi Utama.

Tabel 6

Data Perhitungan EPANET2.0 pada Titik Reservoir dan Titik Sadap Rencana Jalur

\begin{tabular}{|l|r|r|r|r|}
\hline \multicolumn{1}{|c|}{ Node } & \multicolumn{1}{c|}{ Elevation (m) } & \multicolumn{1}{c|}{$\begin{array}{c}\text { Demand } \\
\text { (liter/detik) }\end{array}$} & \multicolumn{1}{c|}{ Head (m) } & \multicolumn{1}{c|}{ Pressure (m) } \\
\hline Reservoir Jatigede (R1) & 220 & 2.000 & 220 & 0 \\
\hline Reservoir Tomo (R2) & 128 & 47,29 & 191,86 & 78,86 \\
\hline Reservoir Kadipaten (R3) & 43 & 356,04 & 124,64 & 44,2 \\
\hline Reservoir Jatiwangi (R4) & 47 & 464,64 & 91,2 & 40,28 \\
\hline Reservoir Palimanan (R5) & 29 & 745 & 69,28 & 48,25 \\
\hline Reservoir Cirebon (R6) & 5 & 387,04 & 53,25 & 71,54 \\
\hline Titik Sadap Tomo (J1) & 128 & 0 & 199,54 & $\mathbf{8 1 , 6 4}$ \\
\hline Titik Sadap Kadipaten (J2) & 43 & 0 & 124,64 & 48,8 \\
\hline Titik Sadap Jatiwangi (J3) & 47 & 0 & 95,8 & 40,78 \\
\hline Titik Sadap Palimanan (J4) & 29 & 0 & 69,78 & \\
\hline
\end{tabular}

Tabel 7

Data Perhitungan EPANET 2.0 pada Titik Reservoir dan Titik Sadap Rencana Jalur

\begin{tabular}{|c|c|c|c|c|c|c|c|}
\hline Link & jalur & $\begin{array}{l}\text { Panjang } \\
(\mathrm{m})\end{array}$ & $\begin{array}{l}\text { Diameter } \\
(\mathrm{mm})\end{array}$ & Rougness & $\begin{array}{l}\text { Velocity } \\
\text { (m/detik) }\end{array}$ & $\begin{array}{l}\text { Unit Headloss } \\
(\mathrm{m} / \mathrm{km})\end{array}$ & Jenis Pipa \\
\hline Pipa 1 & R1-J1 & 3000 & 900 & 140 & 3,14 & 6,82 & HDPE \\
\hline Pipa 2 & $\mathrm{~J} 1-\mathrm{J} 2$ & 11.480 & 900 & 140 & 3,07 & 6,52 & HDPE \\
\hline Pipa 3 & J2-J3 & 10.720 & 1000 & 140 & 2,03 & 2,69 & $\mathrm{HDPE}$ \\
\hline Pipa 4 & J3-J4 & 18.284 & 1000 & 140 & 1,44 & 1,42 & HDPE \\
\hline Pipa 5 & J4-R6 & 15.995 & 710 & 140 & 0,98 & 1,03 & HDPE \\
\hline Pipa 6 & $\mathrm{~J} 1-\mathrm{R} 2$ & 456 & 180 & 140 & 1,86 & 16,85 & $\mathrm{HDPE}$ \\
\hline Pipa 7 & J2-R3 & 631 & 500 & 140 & 1,81 & 5,61 & HDPE \\
\hline Pipa 8 & J3-R4 & 575 & 500 & 140 & 2,37 & 8 & HDPE \\
\hline Pipa 9 & J4-R5 & 259 & 800 & 140 & 1,48 & 1,94 & HDPE \\
\hline
\end{tabular}


Pemilihan Alternatif Jaringan Distribusi Utama (JDU) untuk Pengembangan SPAM Regional di Kabupaten Sumedang, Kabupaten Majalengka, Kabupaten Cirebondan Kota Cirebon

Dalam rencana jalur di atas terdapat beberapa masalah yang mengakibatkan tidak terpenuhinya kriteria hidrolis dalam pipa yaitu dengan kecepatan lebih dari $3 \mathrm{~m} /$ detik dan tekanan yang melebihi $70 \mathrm{~m}$. Maka perlu adanya pemilihan alternatif dalam menentukan jaringan distribusi yang sesuai.

\subsection{Pemilihan Alternatif Jaringan Distribusi Utama}

Dalam menentukan jaringan distribusi, menggunakan pemilihan alternatif jalur dikarenakan terdapat 2 (dua) alternatif yang harus dibandingkan. Penentuan alternatif ditentukan dengan parameter:

1. Panjang dan jenis pipa
2. Bak Pelepas Tekan (BPT)

3. Sisa tekan

4. Kecepatan pada pipa

5. Pengaliran

\section{Alternatif 1}

Perhitungan jaringan distribusi alternatif 1 (satu) menggunakan aplikasi EPANET 2.0 dengan menggunakan rumus Hazen-Williams. Pada alternatif 1 (satu) jaringan distribusi utama ini tidak menggunakan Bak Pelepas Tekan (BPT), melainkan dengan menggunakan 2 bahan pipa yang berbeda untuk pipa distribusinya. Untuk sketsa jaringan distribusinya dapat dilihat pada Gambar 2.

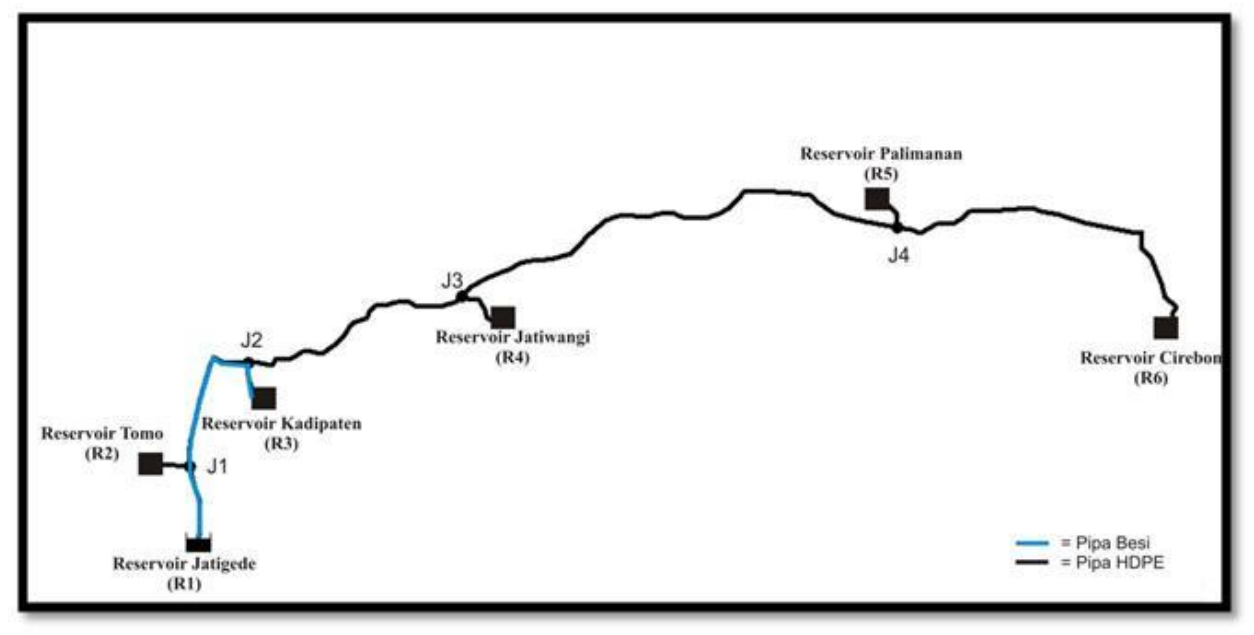

Gambar2

Sketsa Jaringan Distribusi Alternatif 1

Pada Gambar 2 terlihat bahwa terdapat reservoir utama yaitu di Waduk Jatigede yang mengalirkan aliran sebesar 2.000 liter/detik ke tiap reservoir/ offtake pada masing-masing wilayah kajian. Pada alternatif 1 mengunakan 2 (dua) jenis pipa yaitu pipa besi dan pipa HDPE. Penggunaan pipa besi tersebut dimaksudkan untuk mencegah pecahnya pipa 
akibat kecepatan aliran dalam pipa yang lebih untuk jalur alternatif 1 dapat dilihat pada Tabel besar dari $3 \mathrm{~m} /$ detik dan pada sisa tekan lebih 8.

dari 70 meter. Hasil perhitungan EPANET 2.0

Tabel 8

Data Perhitungan EPANET 2.0 pada Titik Reservoir danTitik Sadap Alternatif 1

\begin{tabular}{|l|r|r|r|r|}
\hline \multicolumn{1}{|c|}{ Node } & Elevation (m) & \multicolumn{1}{c|}{$\begin{array}{c}\text { Demand } \\
\text { (liter/detik) }\end{array}$} & Head (m) & Pressure (m) \\
\hline Reservoir Jatigede (R1) & 220 & 2.000 & 220 & 0 \\
\hline Reservoir Tomo (R2) & 128 & 47,29 & 187,72 & 59,72 \\
\hline Reservoir Kadipaten (R3) & 43 & 356,04 & 107,52 & 64,52 \\
\hline Reservoir Jatiwangi (R4) & 47 & 464,64 & 77,17 & 30,17 \\
\hline Reservoir Palimanan (R5) & 29 & 745 & 55,25 & 26,76 \\
\hline Reservoir Cirebon (R6) & 5 & 387,04 & 39,22 & 34,22 \\
\hline Titik Sadap Tomo (J1) & 43 & 0 & 196,53 & 68,53 \\
\hline Titik Sadap Kadipaten (J2) & 47 & 0 & 110,61 & 67,61 \\
\hline Titik Sadap Jatiwangi (J3) & 29 & 0 & 81,77 & 34,77 \\
\hline Titik Sadap Palimanan (J4) & & 0 & 55,25 & 26,76 \\
\hline
\end{tabular}

Tabel 9

Data Perhitungan EPANET 2.0 pada Pipa Distribusi Utama Alternatif 1

\begin{tabular}{|c|c|c|c|c|c|c|c|}
\hline Link & jalur & $\begin{array}{c}\text { Panjang } \\
(\mathbf{m})\end{array}$ & Diameter $(\mathbf{m m})$ & Rougness & $\begin{array}{c}\text { Velocity } \\
(\mathbf{m} / \mathbf{d t k})\end{array}$ & $\begin{array}{c}\text { Unit } \\
\text { Headloss } \\
(\mathbf{m} / \mathbf{k m})\end{array}$ & Jenis Pipa \\
\hline Pipa 1 & R1-J1 & 3000 & 900 & 130 & 3,14 & 7,82 & IRON \\
\hline Pipa 2 & J1-J2 & 11.480 & 900 & 130 & 3,07 & 7,48 & IRON \\
\hline Pipa 3 & J2-J3 & 10.720 & 1000 & 140 & 2,03 & 2,69 & HDPE \\
\hline Pipa 4 & J3-J4 & 18.284 & 1000 & 140 & 1,44 & 1,42 & HDPE \\
\hline Pipa 5 & J4-R6 & 15.995 & 710 & 140 & 0,98 & 1,03 & HDPE \\
\hline Pipa 6 & J1-R2 & 456 & 180 & 130 & 1,86 & 19,33 & IRON \\
\hline Pipa 7 & J2-R3 & 631 & 500 & 140 & 1,81 & 4,89 & HDPE \\
\hline Pipa 8 & J3-R4 & 575 & 500 & 140 & 2,37 & 8 & HDPE \\
\hline Pipa 9 & J4-R5 & 259 & 800 & 140 & 1,48 & 1,94 & HDPE \\
\hline
\end{tabular}

\section{Alternatif 2}

Perhitungan jaringan distribusi alternatif 2 menggunakan metode perhitungan yang sama. Pada alternatif 2 (dua) jaringan distribusi utama ini menggunakan Bak Pelepas Tekan (BPT), dimaksudkan agar mengurangi beban pada pipa yang dapat mengakibatkan pecahnya pipa. Pada alternatif 2 juga hanya menggunakan 1 pipa yang berjenis HDPE, yang memudahkan dalam pemasangan. 


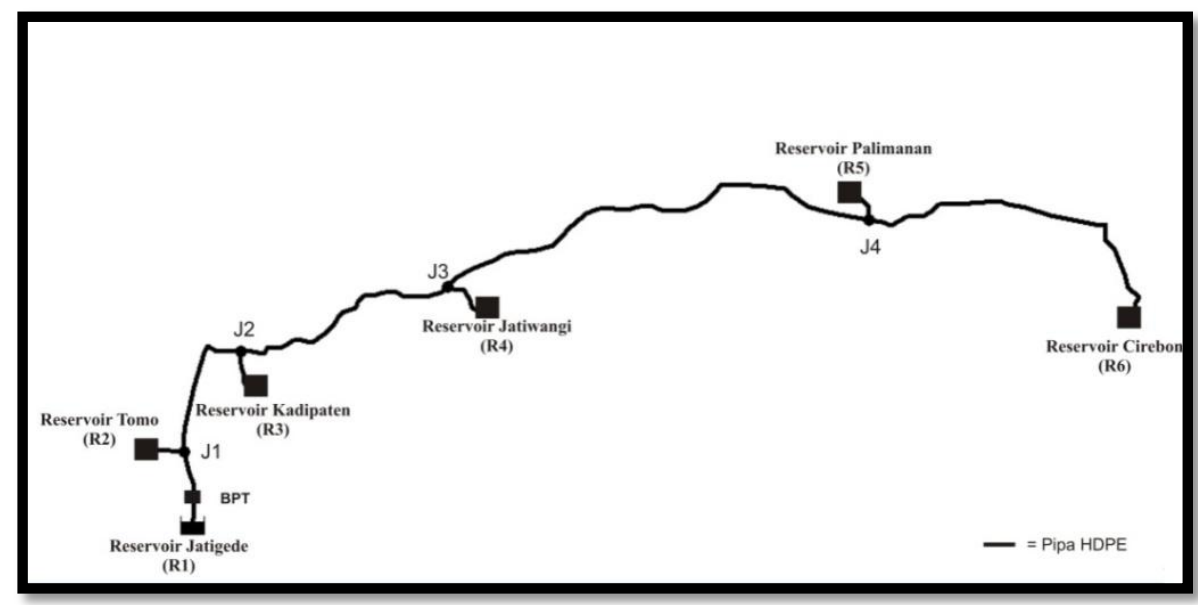

Gambar 3

Sketsa Jaringan Distribusi Utama Alternatif 2

Pada alternatif 2 dilakukan perubahan jenis pipa, yaitu tidak menggunakan jenis pipa besi. Pada alternatif ini dilakukan penggantian jenis pipa dengan pipa yang memiliki kekasaran pipa yang lebih rendah dan memiliki ketahanan dalam menahan kecepatan aliran dalam pipa. Pada alternatif ini penggantian jenis pipa dilakukan pada pipa yang mengalami masalah hidrolis pada parameter kecepatan aliran dalam pipa dan sisa tekan yag melebihi kriteria hidrolis (kecepatan melebihi $3 \mathrm{~m} /$ detik).
Pada Gambar 3 terlihat bahwa terdapat reservoir utama yaitu di Jatigede yang mengalirkan aliran sebesar 2.000 liter/detik ke tiap reservoir/ offtake pada masing-masing wilayah kajian. Pada alternatif ini menggunakan Bak Pelepas Tekan (BPT) pada pipa yang menghubungkan reservoir utama Jatigede dengan titik sadap untuk Reservoir Tomo. Penempatan BPT pada pipa tersebut agar menghasilkan sisa tekan dan kecepatan aliran dalam pipa yang sesuai dengan kriteria perencanaan. Hasil perhitungan EPANET 2.0 untuk jalur alternatif 2 dapat dilihat pada Tabel 10.

Tabel 10

Data Perhitungan EPANET 2.0 pada Titik Reservoir dan Titik Sadap Alternatif 2

\begin{tabular}{|l|c|c|c|c|}
\hline \multicolumn{1}{|c|}{ Node } & $\begin{array}{c}\text { Elevation } \\
(\mathbf{m})\end{array}$ & $\begin{array}{c}\text { Demand } \\
\text { (liter/Detik) }\end{array}$ & Head (m) & Pressure (m) \\
\hline Reservoir Jatigede (R1) & 220 & 2000 & 220 & 0 \\
\hline Reservoir Tomo (R2) & 128 & 47,29 & 149,24 & 21,24 \\
\hline Reservoir Kadipaten (R3) & 43 & 356,04 & 103,46 & 60,46 \\
\hline Reservoir Jatiwangi (R4) & 47 & 464,64 & 73,57 & 26,57 \\
\hline
\end{tabular}




\begin{tabular}{|l|c|c|c|c|}
\hline \multicolumn{1}{|c|}{ Node } & $\begin{array}{c}\text { Elevation } \\
(\mathbf{m})\end{array}$ & $\begin{array}{c}\text { Demand } \\
\text { (liter/Detik) }\end{array}$ & Head (m) & Pressure (m) \\
\hline Reservoir Palimanan (R5) & 29 & 745 & 51,65 & 22,65 \\
\hline Reservoir Cirebon (R6) & 5 & 387,04 & 35,61 & 30,61 \\
\hline Titik Sadap Tomo (J1) & 128 & 0 & 151,84 & 23,84 \\
\hline Titik Sadap Kadipaten (J2) & 43 & 0 & 107 & 64 \\
\hline Titik Sadap Jatiwangi (J3) & 47 & 0 & 78,16 & 31,16 \\
\hline Titik Sadap Palimanan (J4) & 29 & 0 & 52,15 & 23,15 \\
\hline Bak Pelepas Tekan (BPT) & 160 & 2.000 & 160 & 0 \\
\hline
\end{tabular}

Tabel 11

Data Perhitungan EPANET 2.0 pada Pipa Distribusi Utama Alternatif 2

\begin{tabular}{|c|c|c|c|c|c|c|c|}
\hline Link & jalur & $\begin{array}{c}\text { Panjang } \\
(\mathbf{m})\end{array}$ & $\begin{array}{c}\text { Diameter } \\
(\mathbf{m m})\end{array}$ & Rougness & $\begin{array}{c}\text { Velocity } \\
(\mathbf{m} / \mathbf{d e t i k})\end{array}$ & $\begin{array}{c}\text { Unit Headloss } \\
(\mathbf{m} / \mathbf{k m})\end{array}$ & $\begin{array}{c}\text { Jenis } \\
\text { Pipa }\end{array}$ \\
\hline Pipa 1 & R1-BPT & 1.000 & 1.000 & 140 & 2,55 & 4,08 & HDPE \\
\hline Pipa 2 & BPT-J1 & 2.000 & 1.000 & 140 & 2,55 & 4,08 & HDPE \\
\hline Pipa 3 & J1-J2 & 11.480 & 1.000 & 140 & 2,49 & 3,91 & HDPE \\
\hline Pipa 4 & J2-J3 & 10.720 & 1000 & 140 & 2,03 & 2,69 & HDPE \\
\hline Pipa 5 & J3-J4 & 18.284 & 1000 & 140 & 1,44 & 1,42 & HDPE \\
\hline Pipa 6 & J4-R6 & 15.995 & 710 & 140 & 0,98 & 1,03 & HDPE \\
\hline Pipa 7 & J1-R2 & 456 & 225 & 140 & 1,19 & 5,68 & HDPE \\
\hline Pipa 8 & J2-R3 & 631 & 500 & 140 & 1,81 & 5,61 & HDPE \\
\hline Pipa 9 & J3-R4 & 575 & 500 & 140 & 2,37 & 8 & HDPE \\
\hline Pipa 10 & J4-R5 & 259 & 800 & 140 & 1,48 & 1,94 & HDPE \\
\hline
\end{tabular}

\section{Pemilihan Alternatif}

Penentuan alternatif terpilih dilakukan dengan perbandingan data yang telah dihitung dengan aplikasi EPANET 2.0 sebelumnya. Alternatif dipilih dengan melihat kategori jalur dari aspek ekonomis, hidrolis, kemudahan penerapan dan juga perawatan yang mudah.

Tabel 12

Perbandingan Alternatif Jaringan Distribusi Utama

\begin{tabular}{|c|c|c|c|}
\hline No & Parameter & Alternatif 1 & Alternatif 2 \\
\hline \multirow{2}{*}{1.} & \multirow{2}{*}{ Panjang Pipa dan Jenis Pipa } & HDPE $=46.919$ & \multirow{2}{*}{$\mathrm{HDPE}=61.399 \mathrm{~m}$} \\
\hline & & Iron $=14.480 \mathrm{~m}$ & \\
\hline 2. & BPT & 0 & 1 \\
\hline \multicolumn{2}{|r|}{ Perkiraan Biaya } & Rp. 516.522.156.212 & Rp. 470.509 .002 .980 \\
\hline \multirow{2}{*}{3.} & \multirow{2}{*}{ Sisa Tekan } & Paling Besar $=81,64 \mathrm{~m}$ & Paling Besar $=64,00 \mathrm{~m}$ \\
\hline & & Paling Kecil $=40,28 \mathrm{~m}$ & Paling Kecil = 21,24 m \\
\hline \multirow{2}{*}{4.} & \multirow{2}{*}{ Kecepatan Pipa } & Paling Besar $=3,14 \mathrm{~m} / \mathrm{dt}$ & Paling Besar $=2,55 \mathrm{~m} / \mathrm{dt}$ \\
\hline & & Paling Kecil $=0,98 \mathrm{~m} / \mathrm{dt}$ & Paling Kecil $=0,98 \mathrm{~m} / \mathrm{dt}$ \\
\hline 5. & Pengaliran & Gravitasi & Gravitasi \\
\hline
\end{tabular}




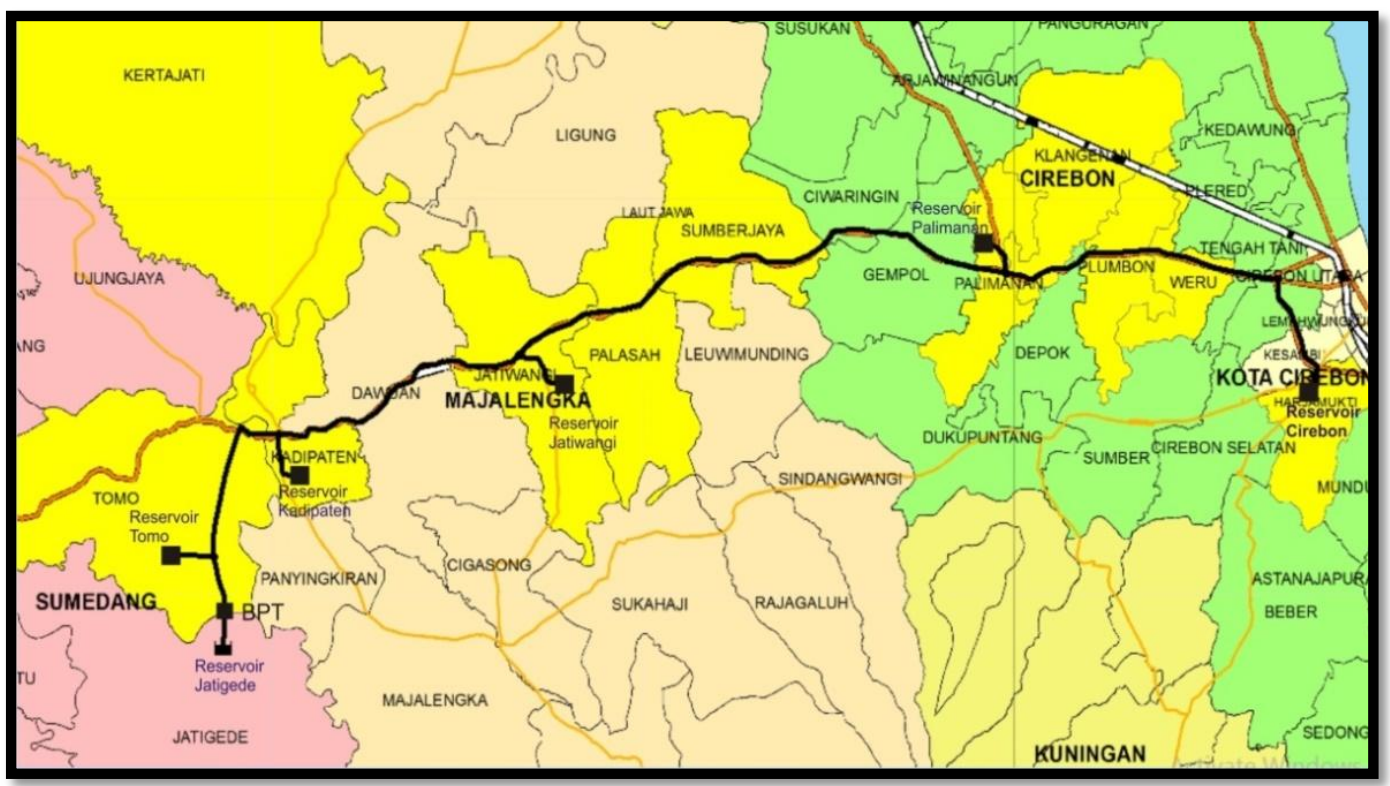

Gambar 4

Peta Jaringan Distribusi Utama Terpilih

Pada Tabel 12 dapat dilihat bahwa dalam segi ekonomis, hidrolis, kemudahan pemasangan dan juga perawatan alternatif 2 (dua) lebih efektik, karena :

1. Dalam segi ekonomis, untuk alternatif 1 dengan menggunakan pipa besi relatif lebih mahal dibandingkan dengan alternatif 2 yang hanya menggunakan pipa jenis HDPE.

2. Dalam segi hidrolis, kedua alternatif sesuai dengan kriteria dalam sisa tekan dan kecepatan aliran karena pipa besi dapat menahan kecepatan aliran dalam pipa yang tinggi. Maka dalam segi hidrolis kedua alternatif sesuai dengan kriteria.

3. Dalam segi kemudahan pemasangan, alternatif 2 (dua) tergolong lebih mudah karena memiliki 1 (satu) jenis pipa yang disambungkan. Sedangkan untuk alternatif 1 (satu) yang menggunakan 2 (dua) pipa yang berbeda akan disulitkan dalam penyambungan pipa yang berbeda dan diperlukan fitting pipa khusus dalam penyambungannya.

4. Dalam perawatan, alternatif 2 (dua) diuntungkan dengan adanya Bak Pelepas Tekan (BPT) yang sekaligus dapat berfungsi sebagai bak kontrol pada sistem jaringan distribusi utama ini.

Maka dapat disimpulkan bahwa alternatif yang terpilih yaitu alternatif 2 (dua) dengan mempertimbangkan faktor-faktor yang telah dijelaskan di atas. 


\section{KESIMPULAN}

Dari hasil kajian mengenai pemilihan alternatif Jaringan Distribusi Utama (JDU) dengan skema SPAM regional dapat disimpulkan sebagai berikut:

1. Ketersediaan (supply) air minum pada setiap wilayah kajian pada kondisi eksisting belum mampu untuk memenuhi kebutuhan domestik dan non domestik, hal tersebut salah satunya dikarenakan tingkat kebocoran air di atas $20 \%$.

2. Debit hasil perhtungan sebagai berikut, kebutuhan rata-rata $(\mathrm{Q})$ adalah 1.333,33 liter/detik, kebutuhan hari maksimum $(Q$ max day) adalah 1.466,66 liter/detik, dan kebutuhan jam puncak ( $Q$ peak hour) adalah 1.999,99 liter/ detik atau 2.000 liter/detik.

3. Reservoir utama dan offtake dipilih sesuai dengan keuntungan dalam segi pengaliran yaitu dengan gravitasi, hasil tersebut didapat dari hasil analisis elevasi daerah layanan masing-masing.
4. Dalam perencanaan yang menggunakan 2 (dua) alternatif dalam menentukan jaringan distribusi utama, maka alternatif ke-2 (dua) yang terpilih dengan mempertimbangkan dalam segi ekonomis paling menguntungkan.

5. Diameter pipa hasil perhitungan alternatif terpilih yaitu berkisar $150 \mathrm{~mm}$ sampai dengan $1000 \mathrm{~mm}$ dengan bahan pipa yang digunakan adalah pipa High Density Poly Ethylene (HDPE).

\section{DAFTAR PUSTAKA}

[1] Bappeda Provinsi Jawa Barat, 2009. RTRWP Jawa Barat 2009-2029.

[2] Steel, E.W., 1953. Water Sewage and Supply. McGraw-Hill.

[3] Hammer, M.J. 1986. Water and Wastewater Technology. John Wiley \& Sons Inc.

[4] Evett, J.B., Liu, C. 1987. Fundamentals of Fluids Mechanics. McGraw Hill, New York. 1987, hal 161. 